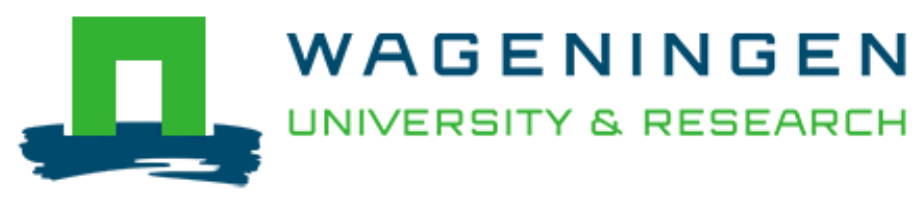

\author{
Sustainable Innovation in Network-Bound Systems: Implications for the \\ Consumption of Water, Waste Water and Electricity Services \\ van Vliet, B. J. M.
}

This is a "Post-Print" accepted manuscript, which has been published in "Journal of Environmental Policy and Planning"

This version is distributed under a non-commercial no derivatives Creative Commons

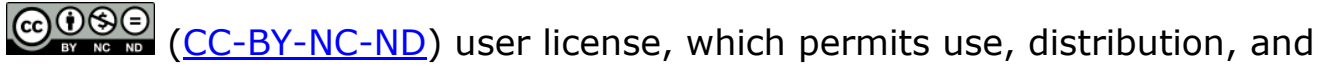
reproduction in any medium, provided the original work is properly cited and not used for commercial purposes. Further, the restriction applies that if you remix, transform, or build upon the material, you may not distribute the modified material.

Please cite this publication as follows:

van Vliet, B. J. M. (2012). Sustainable Innovation in Network-Bound Systems: Implications for the Consumption of Water, Waste Water and Electricity Services. Journal of Environmental Policy and Planning, 14(3), 263-278.

https://doi.org/10.1080/1523908X.2012.702563 


\section{Sustainable Innovation in Network-Bound Systems: Implications for the Consumption of Water, Waste Water and Electricity Services}

BAS J.M. VAN VLIET Environmental Policy Group, Wageningen University, Wageningen, The Netherlands Correspondence Address: Bas J.M. VAN VLIET, Environmental Policy Group, Wageningen University, Hollandseweg 1, 6706 KN Wageningen, The Netherlands., Email: bas.vanvliet@ wur.nl

\section{ABSTRACT}

Network-bound systems are crucial in environmental governance as the usage of their services embody significant environmental impacts. Conditions for network-bound systems providing services to consumers have altered dramatically over the last decades. Liberalization and privatization have led to a differentiation in providers, technologies, products and services, very a-typical for sectors that were formerly characterized by public and uniform modes of provision and consumption. The paper gives an overview of what the socio-technical differentiation of network-bound systems and services imply for end-users and how new relations emerge between users and providers of water and electricity services. Drawing upon contemporary theory development in science and technology studies and in environmental sociology, the paper presents recent empirical findings of differentiation and innovation in drinking water supply, waste water management and electricity supply in the Netherlands. From these developments, the paper concludes that sustainable innovation in network-bound systems leads to a differentiation of not only resources, providers and technologies but also of consumer roles towards provision and use of water and energy services in various ways. Considering that those diverse services are combined in consumers' social practices, a plea is made for a practice-inclusive perspective on understanding and enhancing sustainable innovation in network-bound systems.

KEYWORDS: Network-bound systems, sustainable consumption, social practices, electricity supply, drinking water, waste water management, the Netherlands

\section{Introduction}

It has been widely acknowledged that consumers' connections to and their use of network-bound systems like electricity grids, water supply and sewer works encompass a significant share of their total natural resource use. Most of the literature on this, either from the angle of consumer studies, science and technology studies, or environmental engineering discusses consumption of network-bound services from the perspective of a particular single system. So it is either the consumption of water supply services (Chappells \& Medd, 2008; Hegger et al., 2010; Marks, 2006; Medd \& Marvin, 2008) or electricity supply services (Hughes, 1983; Sauter \& Watson, 2007; Wuestenhagen et al., 2007) or sanitation (Hegger, 2007; Melosi, 2000; van Vliet et al., 2010; Zeeman, 2009) that is the focal point in most of the literature. The similarities and differences between consumer connections and uses of various networkbound systems, or the dynamics therein have rarely been taken up, with the exception of some earlier work on environmental consumption and network-bound systems (Chappells \& Shove, 2005; Southerton et al., 2004; Spaargaren \& van Vliet, 2000). Yet, network-bound systems providing environmentally relevant services to consumers have a lot in common.

First, they roughly share historical patterns and phases of development from private provision in the late nineteenth century via universal service provision by public utilities towards the 1980s to a splintered provision from the late twentieth century on (Graham \& Marvin, 1995; Guy \& Marvin, 1998; Guy et al., 2001; van Vliet et al., 2005).

Second, they can be characterized as Large Technical Systems (Hughes, 1983; Summerton, 1994) as they consist of huge material infrastructures, sunk costs and vested interests among governmental and corporate entities. The change of Large Technical Systems therefore is considered to take the shape of a sociotechnical transition (Geels, 2002; Kemp et al., 2001), an approach for transformative system change involving multiple levels and multiple actors and a long term. 
Finally, the three systems of water supply, waste water management and electricity supply, like other (formerly) public services of rail transport, postal services and telecommunication, have been subject to fierce policy debates on market liberalization and private participation, with various outcomes. Rather than going further into the common aspects between the three network-bound systems on a systemic level, this paper aims to focus on the dynamics at the consumption side of the three systems with respect to innovations for sustainability. The reason for this is first that many innovations for sustainability in water and energy services (think of smart grids, rainwater harvesting) increasingly require some sort of consumer involvement.

It is worth exploring these new roles for consumers in network-bound system innovation, as consumer roles in utility services were until recently non-descript, or labelled as the 'demand side' or 'connections'. And second, whereas the three systems may be distinguishable in terms of their physical lay-out, or legal and policy frameworks, at the consumption level, they come together. It is therefore relevant to explore how consumers combine the use of infrastructures in their daily lives. A combined understanding of changing consumer-provider relations and social practices, and the huge socio-technical, socioenvironmental dynamics that are at stake in network-bound systems would equip us with the means to understand the instruments for the governance of environmental innovation in network-bound systems around the world.

This paper therefore aims to answer the question of how environmental innovation in network-bound systems can be understood and governed if we take it from a consumers' perspective. It draws on recent studies in three network-bound systems: water supply; waste water management and electricity supply in the Netherlands. As for water supply, a research project was executed on consumer market opportunities for water supply companies, based on an inventory of recent innovations in the sector, 3 focus group discussions and a survey among 3452 water consumers (Hegger et al., 2010). Innovation in sanitation was studied in diverse projects over the last decade (van Vliet \& Stein, 2004; van Vliet et al., 2010) all with a focus on consumer perspectives on innovation. Finally, for electricity a literature study supported with some expert interviews was executed on smart grids, smart meters and smart behaviour. The paper will deliver new insights for scholars on consumption and social practices' research related to network-bound systems, or for suppliers and policy makers to inform them about how consumer involvement in the environmental restructuring of urban infrastructures evolves and how to make use of it.

The paper is built up as follows. It starts with a theoretical and historical overview of processes of differentiation in network-bound systems and the parallel emergence of new consumer roles followed by a section on contemporary dynamics in terms of changing conditions of operation, and subsequent emerging innovations and new consumer roles, within the three network-bound systems. Section 4 compares the findings with contemporary scholarly work on consumer- provider relations, networkbound system dynamics and social practices. The conclusions are presented in Section 5.

\section{Differentiation in Network-Bound Systems and the Re-Involvement of the}

\section{Consumer}

Differentiation in network-bound systems can take shape on multiple levels. In this paper, the following levels are distinguished: differentiation of resources, providers and consumers, with a fourth crosscutting level of differentiation of technology and infrastructure. At the level of resources, one could think of a shift from drawing on a single resource towards drawing on multiple resources. In many cases, this will also imply a shift from centralized provision by single units (power plants, pumping stations) towards decentralized provision or distributed generation (EC, 2006; Estache, 1995; Guy \& Marvin, 1998; Hammons, 2008; Kok et al., 2009; Wuestenhagen et al., 2007). A differentiation of resources may be accompanied with a differentiation in providers of services: utility companies will in that case no longer have a monopoly in service provision but feel the competition of providers of the same or different services after liberalization of the utility market. New providers may be of similar size and levels of provision, but not necessarily so. With forms of distributed generation and small-scale provision, new small-scale providers can emerge on the scene. Finally, and mostly forgotten is that also at the level of consumption of network-bound systems differentiation takes place. Here, I refer to the roles of consumers vis-a-vis service provision that can transform from being a captive consumer which refers to obliged consumption of network-bound services provided by a monopolist provider, to consumer roles that can evolve into three categories: (i) a customer, (ii) a citizen-consumer and (iii) a co-provider 
(Chappells, 2003; Sauter \& Watson, 2007; van Vliet et al., 2005). The role-types reflect not only the actual role of end-users in service provision and consumption; rather they are defined by the kind of relationship between providers and consumers. A customer role is defined by a commercial relationship in which providers compete for consumers and consumers have a choice between providers and/or between services. The citizen- consumer role is defined by a relationship coloured by a mutual concern about societal or environmental impacts of energy or water provision and consumption. Lastly, the coprovider role refers to a relationship where consumers share with Sustainable Innovation in NetworkBound Systems other providers the provision of electricity or water services to themselves and/or to other consumers. Conclusively, technologies and infrastructures that form the material backbone of network-bound systems may differentiate from uniform and standardized systems (such as generation units, pipes and cables, taps and sockets) towards a plethora of new technologies and standards such as those for solar energy, biogas, grey water and the like. The process of differentiation in centralized, monopolist utility services into scattered decentralized co-provision of utility services is schematically summarized in Figure 1.

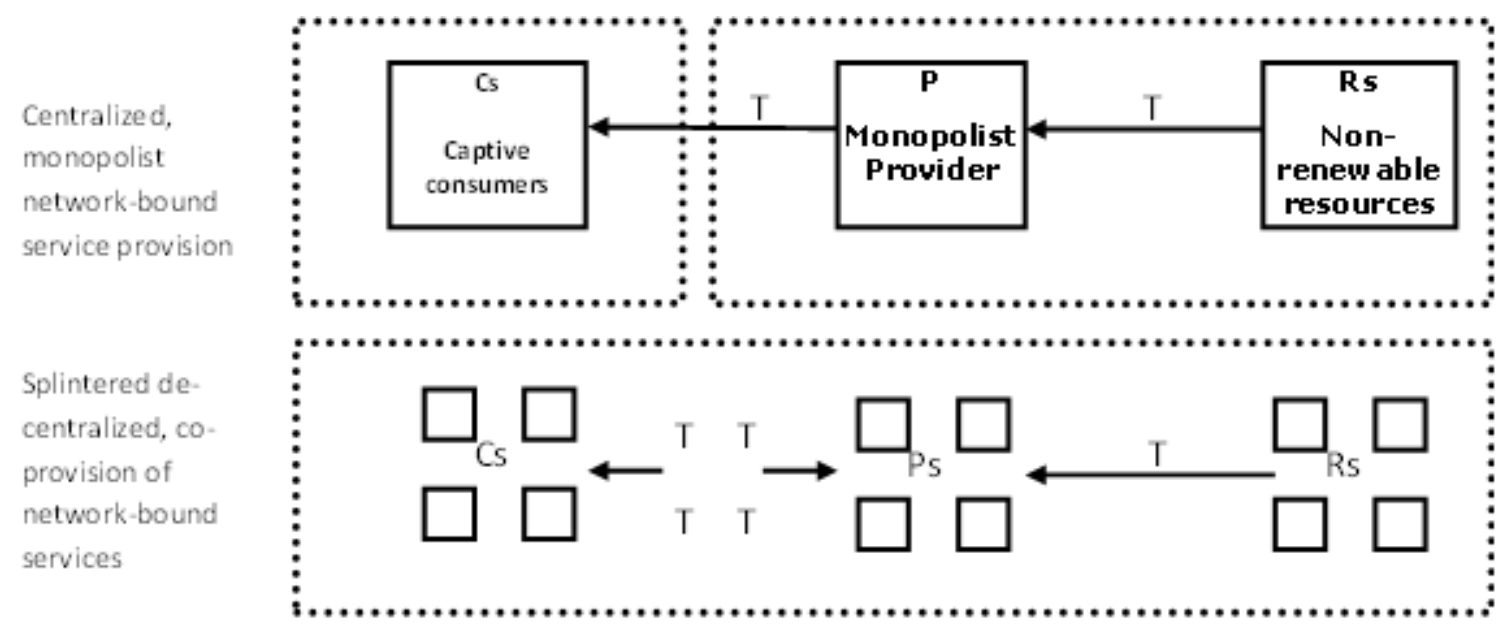

Figure 1. Differentiation of utility services in terms of resources (Rs), technologies (T), providers (Ps) and consumer roles (Cs).

Given the socio-technical dynamics in water supply, waste water and electricity supply systems as sketched above, this raises the question of what this means for (i) the relations between providers and consumers; (ii) the role of consumers in providing the services in general and (iii) more specifically in environmental innovation within network-bound systems. Apart from possible similarities between water supply, electricity supply and waste water services, the differences between them need to be discussed, focusing on the specific differentiation of consumer roles that can be observed in the three networkbound systems under study here. The role categories for consumers are ideal-types which in practice may and certainly will overlap. In the following sections, it is analysed how this role division emerges in innovation projects of water supply, waste water management and electricity supply, respectively.

\section{Socio-Technical Changes in Water Supply, Sanitation and Electricity} Supply Systems

\subsection{Water Supply}

Water supply in the Netherlands has been a public affair since the beginning of the twentieth century. From the highest number of 229 mostly municipal-owned Water Companies before WW-II, due to mergers the number dropped to 100 in 1980 (VEWIN, 2008) and to only 10 in 2010. A crucial period determining the current position of Dutch Water Companies was the 1990s when privatization of Water Companies was openly debated in public and political arenas. Various Figure 1. Differentiation of utility services in terms of resources (Rs), technologies (T), providers (Ps) and consumer roles (Cs). pleas were held opposing or supporting privatization of the sector (Dijkgraaf, 1997), amongst others leading to a water sector-initiated internal benchmark system among Water Companies so as to show that performance monitoring is not an exclusive feature to a privatized market. The discussion was closed 
after the decision by the Minister in 2003 that Water Companies will remain in public hands. ${ }^{1}$ It meant that Water Companies that had merged with energy companies in multi-utilities before had to be split off again as electricity distribution and production activities were to be sold from local and regional authorities to private companies. At the same time, Water Companies became major executers of a national environmental policy program on the avoidance of desiccation of natural areas, one of the pillars of the National Environmental Policy Plan of 1994. Water Companies acted as the main messenger for public campaigns promoting the saving of water and they actively participated in the diffusion and implementation of various water-saving technologies in households (such as dual flush toilets, watersaving showers) (van Vliet, 1995, 2002). Water Companies presented themselves as 'environmental companies' to their customers, while at the same time exploring possibilities for product and services differentiation and for creating new markets, pending the then on-going discussion on liberalization of the water sector. One of the most visible outcomes of this position of Water Companies in the 1990s was a series of household water projects emerging in new residential areas. Household water is a lower quality of water, derived from local surface water or rain water and delivered through a second piped water system to households, with connections to the toilet, the washing machine and the outdoor taps. The assumed environmental benefit of delivering a second water quality for purposes not needing drinking water quality (flushing, washing, gardening) is that precious groundwater can be saved for nature. But, household water projects were also a good opportunity for Water Companies to present themselves as customer-oriented (answering the commonly raised customer remark that flushing toilets with drinking water is a waste), being innovative, modern and environmentally concerned (van Vliet, 2003). Eventually, the experiments came to a halt, after misconnections were made between the two piped systems in a huge project in Utrecht. For the sake of public health, the Minister of Environment in 2003 stopped the experiments and banned new ones in the future. In the years after the decision not to privatize Water Companies, the emphasis in service delivery turned to 'excellent trustworthy service provision including comfort and convenience services'. Water saving or urging consumers to save water has completely disappeared from the agenda, while household water has become an issue better not to be brought up again in consumer surveys. ${ }^{2}$

The main challenge Water Companies are facing nowadays is their lack of opportunities to provide an answer to an increasing number of competitive activities in the water market. Although water delivery is restricted by law to Water Companies alone, increasing competition at the fringes of water service delivery can be observed: from selling bottled water in supermarkets and schools, to providing hot tap water by Energy Companies and rain water devices by third parties. Water Companies' responses to these challenges vary. Some are pushing the limits set by their public monopolist position to reclaim their market share. These companies are now exploring possibilities to enter markets of bottled mineral water; water suspension machines at schools; advisory or certifying Sustainable Innovation in NetworkBound Systems activities. Others keep concentrating on their core business of water supply only. For some Water Companies, finding new markets is a necessity in the longer term, as demand for water supply will decrease due to a shrinking population in the region they serve (Hegger et al., 2009).

\subsubsection{New roles for water consumers.}

With the decision not to privatize the water supply sector, domestic water consumers remain 'captive' aswater supply companies hold a monopoly in water supply in the region and consumers lack the possibility to choose between providers. However, our research findings (Hegger et al., 2010) on new market opportunities for the water sector suggest that client contacts and communication are high on theWater Companies' agenda. Although none of the domestic water users have a choice between providers of tap water, efforts of Water Companies make groups of consumers feel like customers, citizens and co-providers of water services. The customer role is visible in the sense that client communication has gained importance: regular monitoring of client contacts, satisfaction and complaint handling is done to improve services and as input for an indicator in the sector wide tri-annual benchmark (VEWIN, 2007). The role of citizen-consumers emerges when clients are invited to participate in development projects their Water Company is involved in, like the assistance Water Companies offer in water and sanitation projects in the South. The co-provision role can be observed in cases where water users install rainwater or grey water recycling systems for certain water uses in and around their homes. This picture of consumer roles vis-a-vis Water Companies is however rather onesided as it only sketches a provider point of view towards possible or expected consumer roles. In two subsequent research projects, it was identified how water consumers view their Water Companies' and their own roles in terms of water provision and innovation. The first project aimed at qualitative assessments by experts and consumer focus groups of environmental innovations and consumer 
expectations on innovations and roles of Water Companies therein (Hegger et al., 2009). The conclusion is that a general shift can be observed from supply-side thinking towards more consumer-inclusive innovation strategies in the Dutch water supply sector. Water Companies are investigating and experimenting with new roles to complement their classical role of being an upstream operating (public) provider of water. Water managers are now considering several innovation routes also at the downstream end of the water chain and start to think beyond the core business of piped drinking water supply. The new provider roles identified vary from being 'supplier of other than merely plain water flows', 'consultant/advisor', 'certifier', 'provider of services', 'provider of products', to a role as 'company with an active consumer orientation'. These different roles can be said to represent different degrees of orientation on consumers' water practices, different forms of envisaged inter-provider competition and different levels of environmental ambition. Both our qualitative (focus groups) and quantitative (survey) assessments show that consumers associate Water Supply Companies with efforts for the environment, high water quality and public health. Much less obvious for consumers is the potential commitment of their providers with 'luxury' and 'wellness' products and services. Consumers do envisage new services and new roles for the water industry, but only as long as they build upon and are in line with the classical view of Water Companies as public organizations that act responsibly and do not engage in risky, commercial services (Hegger et al., 2010). In terms of consumer roles, this points to a preference of consumers not to be treated as market actors (customers) but as citizen- consumers of a trustworthy, and societal and environmentally sound public service.

\subsection{Wastewater and Sanitation}

The Netherlands is one of the most densely sewered countries in the world, with $111,000 \mathrm{~km}$ of sewer pipes and $99.6 \%$ of households being connected to them (Rioned, 2009). For historical reasons, there has been a separation between responsibilities for water supply (by public companies), sewerage services (mostly by municipalities) and sewerage treatment (regional Water Boards) (Juuti \& Katko, 2005). The provision of sewerage and waste water services to consumers has been the most public as well as the most 'invisible' service provision of the three services discussed. All domestic consumers pay either one of the two fixed rates for wastewater treatment, either for a single or for a multiple person household. Through municipal taxes they pay for sewerage operation and maintenance. Efforts to integrate tariffs for water supply and sewerage never materialized, at least not to the full, due to disagreements on cost recovery of services between Water Companies and Water Boards. Also the integration of Water Supply Companies and Water Boards have been proposed several times but have not been followed up, except for the city of Amsterdam, where the municipal Water Supply Company and parts of the Regional Water Board have been brought together under one company called Waternet. Similar to the drinking water supply sector, the past decades have seen a process of up-scaling and merging of Water Boards. Nowadays, there are 27 Water Boards left, geographically designated according to water sheds, and institutionally sitting between provinces and municipalities. Water Boards constitute the fourth governmental level next to local, provincial and national governments. While formerly the general board consisted of representatives of stakeholders like farmers and Water Companies, since 1992 General Board members are elected by all constituents in the region, including domestic consumers. The turnout of domestic consumers at Water Board elections held so far are however notoriously low (i.e. $23 \%$ in 2004 , $24 \%$ in 20083). With $47 \%$ of all sewer pipes being built before 1980 (Rioned, 2009), huge replacement investments are needed in the near future. Also the replacement of mixed sewers by separated sewer systems for storm water and waste water requires huge investments. Sewer charges are therefore expected to double in the years to come (Rioned, 2005). Emerging challenges for the current sewer and treatment systems are the persistence of medicine residues in waste water treatment effluent and the emission of Phosphorus and Nitrogen to surface waters (Waste water treatment plants count for $41 \%$ and $25 \%$ of total emissions of $\mathrm{P}$ and $\mathrm{N}$, respectively (Rioned, 2009)).

Although the central sewer system and waste water treatment plants are by far the dominating technologies for waste water collection and treatment, there is a growing number of projects emerging, aiming at research, development and implementation of more decentralized collection, treatment and reuse systems for domestic waste water (Hegger, 2007; Zeeman, 2009). Such projects are typically niche developments, in new built areas and initiated by various consortia consisting ofWater Boards, researchers, municipalities, housing corporations and citizen groups. The decentralized systems vary in character and aim, a.o. urine separation Sustainable Innovation in Network-Bound Systems and reuse; nutrient $(\mathrm{P}, \mathrm{N})$ recovery from black water; water saving and biogas production. They are implemented as 
alternatives to the central sewer and treatment systems that are validated as being over-dimensioned, and spilling water, nutrients, materials and energy (Lens et al., 2001). Alternative treatment of toilet and biowaste in, i.e. on-site anaerobic digesters keeps wastes concentrated, offers better opportunities for nutrient recovery and treatment of micro-pollutants and medicine residues, and for the production of biogas (Zeeman, 2009).

\subsubsection{New consumer roles in waste water management.}

Traditionally, the most anonymous and captive consumers are to be found at the beginning of waste water networks. The production of waste water is not metered, nor individually monitored, and connecting to a sewer system is an obligation for all households. Other consumer roles are required and actually emerge at the margins of the bigger waste water systems, notably in the experiments with various kinds of new-decentralized-sanitation. Hegger (2007) has investigated many of such projects in Western Europe and categorized them in either expert-led or citizen-consumer-driven projects. An example of the first are two new sanitation projects in Sneek (Lemmerweg Oost and Noorderhoek), where 32 houses (Lemmerweg Oost) and 32 appartments and a retirement home (Noorderhoek) are connected to vacuum sewer systems that lead toilet waste to an anaerobic digester tank within the same neighbourhood. Similar to other expert-driven new sanitation projects, the consortium of a housing corporation, the regional Water Board, and a production company was eager not to bother householders in the design or management of the system. The only aspect householders found different is the shape of the toilet, the vacuum flush method and the different sound it makes. Our interviews in Noorderhoek (Naus \& van Vliet, 2012) were focussed on the skills and meanings of the social practice of toilet use. The skills of using a toilet are roughly the same as with conventional toilets. The flushing itself is most different from normal flush toilets. Flushing means pushing hard on a button which opens the valve with a short and loud 'bang' that resonates throughout the building. Because of this noise (up to $96 \mathrm{~dB}$, Telkamp et al., 2008) people developed different strategies to avoid the nuisance. Many postpone the nightly flushing until the next day, others do not flush at all after only peeing and one lady told us that she covers the toilet lid with her winter coat every time before pushing the flush button. In terms of 'meaning' we found pride among respondents to be pioneers of a new environmentally sound system. Saving water was mostly mentioned as the main goal of the project, rather than producing energy. The toilet is considered modern, high tech and hygienic and takes the principle of 'flush and forget' to the extreme.

Interviews with householders in both expert-driven projects show that more involvement from their side in the design, management and display of the system to the outside world would have been preferred (Hegger, 2007). Providers too easily seem to assume that consumers would like to be kept away from waste water management, even when the treatment systems become decentralized to a neighbourhood level. In case of toilet systems like urine separation or composting toilets that do need behavioural change (like men having to sit down on urine separation toilets, or managing the composting conditions and emptying the tank), it would be even necessary to involve end-users as co-providers of sanitation services. In so-called citizen-consumer-driven sanitation projects like Eva Lanxmeer in Culemborg, where residents initiated and co-designed their own sustainable housing estate (van Vliet, 2006), the role of consumers is obviously much more visible. Householders see themselves here as co-providers of decentralized sanitation systems and organize the modes of management and maintenance of the grey water treatment systems in place among themselves and the other providers of waste water services. Consumer roles become an object of negotiation rather than fixed especially in the planning phase and during the initial years of living in the project (Cuijpers, 2006; Hegger, 2007). Overall, the dominant role of users in waste water systems, including most of the innovative pilot projects, is still a captive consumer, while only in a few citizen-driven innovation projects, roles of citizen-consumer and coprovider come to the surface.

\subsection{Electricity Supply}

Over the last decades, the electricity sector in the Netherlands has been the most dynamic of the three network-bound systems discussed. Apart from several mergers between regional electricity production and distribution companies, the assets and services of electricity production, transmission, network management and distribution have also been separately sold to international utility companies or transformed into new public companies. A major step away from regional monopolies and 'captive consumership' was the Electricity Act of 1998, which specified that domestic consumers may choose from which energy company they wish to buy their electricity. Initially, this right was reserved for green electricity only, with the intention to raise the demand for renewable energy. Later on, all kinds of 
electricity could be sold competitively on the domestic market. Since 2000, many new intermediary companies without production facilities or distribution networks have entered the consumer market, buying electricity produced from various national or foreign production facilities and passing it on to consumers in packages of green, grey or cheap electricity over existing distribution networks managed by public companies. In 2006, with reference to upcoming EU legislation and at the cost of huge opposition from the side of Energy Companies, the Dutch government forced the Energy Companies by law4 to split activities of network management from energy production and distribution and to create separate companies for both before January 2011. This enables the privatization of energy production and distribution while keeping the distribution and transmission networks in public hands. Since this law was passed in 2007, several public shareholders of regional energy companies (provinces and municipalities) have sold their shares to multinational energy companies like RWE and E-on, while new regional distribution network companies (grid administrators) have been created (i.e. Enexis, Alliander). ${ }^{5}$ It is too early to assess whether the creation of separate public grid administrators indeed results in the intended investments in the public distribution networks. Remarkable however is that the initiative and key role in the development and implementation of 'smart grids' and, connected to that, the electrical car is especially taken up by the newly created public grid administrators. Sustainable Innovation in Network-Bound Systems

3.3.1 New consumer roles in electricity supply.

Compared to water and sanitation, the electricity sector is the most dynamic network-bound system with respect to changing provider-consumer relations. After the introduction of competition between electricity providers, the sector continued to change long-standing consumer-provider relations, culminating in the development of decentralized smart grids and electrical cars. Since the 1990s, householders can become involved as investors, owners and (co)regulators of renewable energy by installing solar PV panels, micro CHP or even wind turbines and delivering excess electricity to the distribution grid. Enhancement of this co-provider role may become essential for significant deployment of smart grids. A smart grid is an electricity network characterized by the active management of both information and energy flows in order to control practices of distributed generation, storage, consumption and flexible electricity demand. These practices are happening both before and after the (smart) meter installed in households and they involve multiple actors and different temporal-spatial dynamics (EC, 2006). Smart grids are also needed for the development of the electric car and more specifically the infrastructure to load its batteries. Fine-tuning and timing of load capacity in the network is crucial for the electrical car project to succeed and so is consumer behaviour. Energy companies are now preparing to roll out smart meters to millions of Dutch households. In contrast to conventional meters, which display aggregate KW hours only being read once a year, smart meters can display realtime and aggregated energy use, in various household devices, and can be read anywhere at any time via the internet. They are being advertised as convenience devices ('Control and monitor your home from anywhere'; 'Set your mind at ease with customisable security alerts'; 'Expandable to suit your needs'6), but smart meters do have other roles to play: to accommodate demand side management, tariff differentiation, distributed generation, and the development of smart grids and loading capacity for electrical cars. The social practice of household energy monitoring comprising the materials, skills and meaning (Shove, 2010) will definitely change in all three aspects. Materials: meters and various devices and infrastructures to display will definitely change, as will the skills of meter reading and interpreting. In terms of meanings around smart energy monitoring, a huge variety can be observed: smart meters may be seen as a vehicle of convenience, as an intrusion from the utility sector into the private domain or as a symbol of commodification of what had been considered universal services. Others have defined metering as the method to facilitate the necessary monitoring of energy use; to internalize energy consumption levels before consumers can be motivated to resource saving behaviour (Vollink \& Meertens, 2006). Smart meters enable a further step in monitoring. Where previously suppliers could only periodically monitor aggregate energy data, they now gain access to a range of detailed data monitored remotely and in real-time. Conversely, citizen- consumers gain instant access to data on energy efficiency, sources, prices etc. With the materialization of these information flows, the previously clear-cut divide between the (energy) system and the citizen-consumer's life-world becomes blurred and needs to be renegotiated. Apart from such vertical information flows, also 'horizontal' information flows will be travelling between citizen-consumers. Through detailed monitoring of energy consumption inside the household (self-monitoring), it becomes possible to trace energy use back to specific practices (e.g. heating, lighting, transport) and to specific persons. It may also become possible for consumers to compare their consumption to that of their neighbours, and to track energy generation/ storage to individual households and companies. Disclosure in the context of horizontal information flows can be 
analytically distinguished into positive forms of 'self-disclosure' and un-wanted forms of 'self-exposure'. Self-disclosure might yield new forms of solidarity and (energy) cooperation among citizen- consumers. But, the unwanted self-exposure (the disclosure of matters that people do not want to become visible for others) can lead to 'fencing-off' efforts (Naus, 2011).

The social practice of (smart) energy monitoring has now been taken up by some enthusiast people while others are either indifferent to it or opposing it all together. For the 'old-school' data loggers who have always been counting their KWhs by regular meter readings, and for the technological gadget lovers, a smart meter would probably be a welcome device. For some others however, the self-monitoring would be seen as an additional household chore. More to the forefront in the debate about smart metering is the issue of privacy around smart metering. There are many people who worry that the more detailed information is gained on energy use inside one's home (the detailed energy demand patterns reveal pretty much the daily chores of householders, when they are at home, when they shower, when they go to bed etc.), the bigger the chance that such information will be disclosed to others than to the consumers themselves. Differentiation in appreciation of smart meters and therefore the differentiation in social practices around energy monitoring stems from lifestyle-related differences between consumers. Electricity users of the nearby future will have to make up their minds about the 'smart monitoring' of their domestic, sustainable energy production and consumption while not intruding on their privacy which also depends upon their role in management and control over distributed generation and metering. Citizen consumers are also challenged by the new possibilities of smart grids to reorganize their routines of mobility, showering, heating and lighting to make their lifestyles more sustainable. In short, future 'smart' consumer behaviour in relation to smart grids entails the strategic balancing of being energy customers, co-producer, citizen and consumer at the same time while making choices about economy, privacy and sustainability.

\section{Cross-Sectoral Lessons and Implications for Studying Network-Bound System Dynamics and Social Practices}

Since the 1980s, all three systems have departed from their position to consider consumers as 'connections' only to be bothered with meter readings or paying the bill. Consumers have gained the attention of providers in several ways: as a target group for adopting innovations and new services; as clients to offer competitive deals on the electricity market; as co-providers of (solar) electricity or as concerned citizens to involve in and pay for water projects in the South. Second, the socio-technical innovations that have been taken place in the three sectors have at least partly been motivated by environmental issues and not only rhetorically. Examples of such innovations are the experiments and largerscale implementation of solar panels, wind energy, biomass and Combined Sustainable Innovation in Network-Bound Systems Heat Power systems; household water systems, water saving devices, grey water treatment systems, vacuum toilets, composting toilets, urine separation toilets. Third and strikingly, most of these innovations involve a downscaling of key technologies and infrastructures providing the services, which means that the formerly distinct domains of central provision and localized consumption of network-bound services have become mixed up.

As illustrated in Figure 1, the relationships between providers and consumers and the distinctions between the domains of providers and consumers have become blurred in all three sectors. Consumers play many different roles in the three network-bound systems and these roles even further diverge with ongoing innovation and decentralization within those systems. Strikingly, the different consumers of water, electricity and wastewater services with the different roles assigned to them are in reality of course the very same domestic consumers who smoothly combine the use of all network-bound systems together within their household practices. From a consumer point of view, it is therefore quite obvious to compare, combine but also easy to get lost in the complicated institutional boundaries between systems of energy or water services provision. For instance in the focus groups with water consumers, participants were using the terms Water Company and Water Board interchangeably and were comparing their service levels and communication styles with Energy Companies and telecom services. The precise distinctions between electricity production, distribution or grid administrators were not familiar to these consumers either. This process of blurring is being accelerated by boundary crossing activities of water, energy and wastewater sectors as well as new providers in their search for new markets and environmental innovation. In some new-built residential areas, Energy Companies are now starting to deliver hot tap water to householders through a neighbourhood-scale CHP system. As about half of domestic water consumption comprises water that is heated for diverse high-valued purposes (most 
notably bathing, showering) Water Companies fear that they will be reduced to mainly toilet flush water providers (Hegger et al., 2009). Apart from Energy Companies being involved in water supply, many other boundary crossings occur: Water Boards being involved in new decentralized sanitation providing biogas for energy production (as in the new sanitation projects in Sneek); electricity network companies providing electric car mobility services ${ }^{7}$; Gas Companies applying micro-heat power installations in households (Hommelberg et al., 2007) and thereby turning domestic gas consumers into electricity providers. After the unbundling and fragmentation of network-bound systems and the separation of vertical and horizontal roles and types of consumers, space has been created for intermediaries to take up roles formerly divided between consumers and providers of services (Marvin \& Medd, 2004). Such new intermediary service providers that have entered the splintered utility markets are for instance providers of grey water treatment systems, water dispensers, or solar energy systems; domestic energy consultants, web-based services for energy tariffs and services comparison, and companies mediating electrical car demand and availability of loading stations. ${ }^{8}$ There is no sign at all that these developments will eventually end up in clearly distinguishable and stable constellations of network provision and consumption as it was before liberalization and decentralization. As environmental innovation and liberalization both continue to be the key conditions in network-bound system dynamics-and as we have seen both conditions are drivers for unbundling and decentralization-a further differentiation of provision and blurring of domains of consumption and provision can be expected.

The implications for research on the governance of network-bound systems are multi-fold. First of all, the analysis above implies that there is a need to address consumers not just as energy consumers, or water consumers, or consumers of waste water services but as 'knowledgeable agents' combining the use of all network-bound services in a series of daily social practices and in various roles. Such research on social practices related to network-bound services rather than on consumption of single products or services can build on the work of Shove and Walker (2010), Reckwitz (2002) and Schatzki (2009) on social practices. In fact, the last decade has seen work in this direction already evolving (Brand 2005; Chappells \& Medd, 2008; Hegger et al., 2007; Shove, 2010; Spaargaren, 2003). More research however is needed, in particular into the spill-over effects between multiple network-bound system uses within domestic social practices, for instance, in what it means for consumers to use a smart meter in electricity consumption and how that would influence the use of and appreciation for 'smart' water meters, when both systems of water and electricity will be utilized in combination within the social practices of bathing, or cooking.

The other implication of the analysis is that in terms of thinking about urban governance in relation to network-bound systems, some widely distinct disciplines need to be brought together. The dynamics in network-bound systems are stretching in a number of dimensions: socially in terms of new consumerprovider relations, technically in terms of new generation, treatment, distribution and monitoring systems, and spatially in terms of differentiation in geographical scales of network-bound systems. Monstadt (2009) has pleaded for the integration of so-far rather distinct bodies of literature dealing with urban infrastructure dynamics: history of technology studies; urban studies and science and technology studies. New studies labelled 'the urban political ecology of infrastructures' would indeed be needed to embrace the emerging complex relationships between socio-environmental, socio-technical and urban infrastructure development as they have been sketched in this paper.

\section{Conclusions}

Contemporary environmental innovations in energy, water and waste water services should be seen as processes of differentiation in resources, providers, technologies and consumer roles. Recent studies on waste water innovations, water supply services and the development of smart electricity grids in the Netherlands show that new consumer roles vary widely among the sectors. In water supply and sanitation, consumers remain captive consumers although they are increasingly being treated as customers and citizens, especially in case of water supply. In terms of electricity supply, consumers have now become customers of commercially delivered electricity services or co-providers of electricity through various means, or citizen-consumers who are concerned about the climate impact of their energy consumption. It should be emphasized that consumers do not separately consume water, electricity or waste water services or would necessarily act differently in all these sectors, but that they (smoothly) combine their use of network-bound services in a range of social practices. If we would take the role of the consumers in environmental innovation seriously, the dynamics in all network-bound systems should therefore be discussed in Sustainable Innovation in Network-Bound Systems relation to each other as well as to the domestic social practices in which these networks play a role. The combined 
perspectives of differentiation in network-bound systems and consumer roles and that of social practices in which the use of network-bound services come together help in understanding the current sociotechnical dynamics that are at stake in several network-bound systems and in domestic consumption today. The evolving research agenda into social practices around the usage of network-bound system services leads to a better understanding of contemporary consumer involvement in network-bound systems and environmental innovation.

Notes

1. 'Wijziging van de Waterleidingwet (eigendom waterleidingbedrijven)' Eerste Kamer der StatenGeneraal (2003), 28 339, 9 December 2003 (http://www.eerstekamer.nl/9324000/1/ j9vvgh5ihkk7kof/vgm1kje0bqtk/f=y.pdf).

2. From project meetings minutes with marketing specialists of Dutch Water Companies, 2008 and 2009 (Hegger et al., 2009, 2010).

3. Available at http://nos.nl/artikel/80575-opkomst-waterschapsverkiezingen-24.html

4. Act of 23 November 2006 to amend the Electricity Act 1998 and Gas Act in relation to independent network management.

5. Companies that have not yet split their network management and production and distribution activities continued opposition against the Law and were successful in June 2010 when the Court of Justice determined in an appeal case that the Law was not in line with European Law (Court of Justice The Hague, cases 200.035.392/01/02/03, 22 June 2010).

6. Available at www.alertme.com (accessed 1 March 2012).

7. Network company Enexis has launched the 'Mobile Smart Grid' see: www. mobilesmartgrid.eu

8. That is, Remotion, see www.remotion. biz

\section{References}

Brand, R. (2005) Urban infrastructures and sustainable social practices, Journal of Urban Technology, 12(2), pp. 1-25.

Chappells, H. (2003) Re-Conceptualizing Electricity and Water: Institutions, Infrastructures and the Construction of Demand (Lancaster: Lancaster University).

Chappells, H. \& Medd, W. (2008) What is fair? Tensions between sustainable and equitable domestic water consumption in England and Wales, Local Environment, 13(8), pp. 725-741.

Cuijpers, Y. (2006) Verwaterend burgerschap: technologisch burgerschap rondom een wijkwatersysteem, MSc thesis, Enschede, Twente University.

Dijkgraaf, E. e. a. (1997) Mogelijkheden tot Marktwerking in de Nederlandse Watersector (Rotterdam: Ministerie van Economische Zaken/EUR). EC (2006) European Technology Platform Smart Grids: Vision and strategy for European Electricity Networks for the Future (Brussels: European Commission).

Estache, A. (1995) Decentralizing Infrastructure. Advantages and Limitations (Washingtion, DC: World Bank).

Geels, F. W. (2002) Technological transitions as evolutionary reconfiguration processes: A multi-level perspective and a case-study, Research Policy, 31(8-9), pp. 1257-1274.

Graham, S. \& Marvin, S. (1995) More than ducts and wires: Post-fordism, cities and utility networks, in: P. Healy (Ed), Managing Cities: The New Urban Context, pp. 169-190 (London: Wiley).

Guy, S. \& Marvin, S. (1998) Electricity in the marketplace: Reconfiguring the consumption of essential resources, Local Environment, 3(3), pp. 313-331. 
Guy, S., Marvin, S. \& Moss, T. (Eds) (2001) Urban Infrastructure in Transition: Networks, Buildings, Plans (London: Earthscan).

Hammons, T. J. (2008) Integrating renewable energy sources into European grids, International J ournal of Electrical Power \& Energy Systems, 30(8), pp. 462-475.

Hegger, D. (2007) Greening sanitary systems: An end-user perspective, PhD thesis, Wageningen University, Wageningen.

Hegger, D. L. T., van Vliet, J. \& van Vliet, B. J. M. (2007) Niche management and its contribution to regime change: The case of innovation in sanitation, Technology Analysis \& Strategic Management, 19(6), pp. 729-746.

Hegger, D. L. T., van Vliet, B. J. M., Spaargaren, G. \& Frijns, J. A. G. (2009) Meer dan drinkwater alleen. Nieuwe relaties tussen drinkwaterbedrijf en consument (Wageningen/Nieuwegein: WUR Environmental Policy/KWR Watercycle Research Institute).

Hegger, D. L. T., Spaargaren, G., van Vliet, B. J. M. \& Frijns, J. (2010) Consumer-inclusive innovation strategies for the Dutch water supply sector: Opportunities for more sustainable products and services, NJ AS-Wageningen Journal of Life Sciences, 58(1-2), pp. 49-56.

Hommelberg, M. P. F., Roossien, B., Warmer, J. K. \& Kok, F. J. (2007) Aggregatie Van Micro-wkk's in een Virtuele Centrale. First Trial Smart Power System. Openbare Eindrapportage (Petten: ECN).

Hughes, T. P. (1983) Networks of Power: Electrification in Western Society, 1880- 1930 (Baltimore: John Hopkins University Press).

J uuti, P. S. \& Katko, T. S. (Eds) (2005) Water, Time and European Cities, History Matters for the Future (Tampere: EU Water Time Project).

Kemp, R., Asselt, M. v. \& Rotmans, J. (2001) More evolution than revolution: Transition management in public policy 1. Available at http://hdl.handle.net/1765/7672

Kok, K., Karnouskos, S., Nestle, D., Dimeas, A., Weidlich, A., Warmer, C., Strauss, P., Buchholz, B., Drenkard, S., Hatziargyriou, N. \& Lioliou, V. (2009) Smart houses for a smart grid. Paper presented at the 20th International Conference on Electricity Distribution, CIRED, Prague.

Lens, P., Zeeman, G. \& Lettinga, G. (Eds) (2001) Decentralised Sanitation and Reuse: Concepts, Systems and Implementation (London: IWA Publishing).

Marks, J. S. (2006) Taking the public seriously: The case of potable and non potable reuse, Desalination, 187(1-3), pp. 137-147.

Marvin, S. \& Medd, W. (2004) Sustainable infrastructures by Proxy? Intermediation beyond the production- consumption nexus, in: D. Southerton, H. Chappells \& B. van Vliet (Eds), Sustainable Consumption: The Implications of Changing Infrastructures of Provision, pp. 81-94 (Cheltenham: Edward Elger).

Medd,W. \& Marvin, S. (2008) Making water work: Intermediating between regional strategy and local practice, Environment and Planning D: Society and Space, 26, pp. 280-299.

Melosi,M. (2000) The Sanitary City. Urban Infrastructure in America from Colonial Times to the Present (Baltimore: John Hopkins University Press).

Monstadt, J. (2009) Conceptualizing the political ecology of urban infrastructures: Insights from technology and urban studies, Environment and Planning A, 41(8), pp. 1924-1942.

Naus, J. (2011) Unpublished PhD application on Informational Governance, Environmental Policy Group Wageningen University. 
Reckwitz, A. (2002) Toward a theory of social practices, European Journal of Social Theory, 5(2), ๆ pp. 243-263.

Rioned (2005) Toestand van de Riolering. Available at http://www.riool.net/riool/binary/retrieveFile instanceid=20\&itemid=997\&style=default (accessed 27 August 2010).

Rioned (2009) Riool in Cijfers 2009-2010 (Ede: Stichting Rioned).

Sauter, R. \&Watson, J. (2007) Strategies for the deployment of micro-generation: Implications for social acceptance, Energy Policy, 35(5), pp. 2770-2779.

Schatzki, T. (2009) Time, space and the organization of social life, in: E. Shove, F. Trentmann \& R. Wilk (Eds), Time, Consumption and Everyday Life, pp. 35-48 (Oxford: Berg).

Shove, E. (2010) Beyond the ABC: Climate change policy and theories of social change, Environment and Planning A, 42(6), pp. 1273-1285.

Shove, E. \& Walker, G. (2010) Governing transitions in the sustainability of everyday life, Research Policy, 39(4), pp. 471-476.

Southerton, D., Chappells, H. \& van Vliet, B. (Eds) (2004) Sustainable Consumption: The Implications of Changing Infrastructures of Provision (Cheltenham: Elgar).

Spaargaren, G. (2003) Sustainable consumption: A theoretical and environmental policy perspective, Society \& Natural Resources, 16(8), pp. 687-701.

Spaargaren, G. \& van Vliet, B. (2000) Lifestyles, consumption and the environment: The ecological modernisation of domestic consumption, Environmental Politics, 9(1), pp. 50-76.

Summerton, J. (1994) Changing Large Technical Systems (Boulder: Westview Press). Sustainable Innovation in Network-Bound Systems

Telkamp, P., Mels, A. \& van den Bulk, J. (2008) Praktijkervaringen met vacuüm technologie voor toiletten, H2O, 2008(10), pp. 50-52.

van Vliet, B. (1995) Waterbesparing: Oover spoeling en verspilling: een vooronderzoek naar de ontwikkeling en verspreiding van diverse technologieën met als doel waterbesparing in huishoudens (Wageningen: LU, Wetenschapswinkel).

van Vliet, B. (2002) Greening the Grid: The Ecological Modernisation of Network-Bound Systems (Wageningen: Wageningen University).

van Vliet, B. (2003) Differentiation and ecological modernization in water and electricity provision and consumption, Innovation, 16(1), p. 29.

van Vliet, B. (2006) The sustainable transformation of sanitation, in: J.P. Voss, D. Bauknecht \& R. Kemp (Eds), Reflexive Governance for Sustainable Development, pp. 337-354 (Cheltenham: Edward Elgar).

van Vliet, B. \& Stein, N. (2004) New consumer roles in waste water management, Local Environment: The International J ournal of J ustice and Sustainability, 9(4), pp. 353-366.

van Vliet, B., Chappells, H. \& Shove, E. (2005) Infrastructures of Consumption: Environmental Innovation in the Utility Industries (London [etc.]: Earthscan).

van Vliet, B., Spaargaren, G. \& Oosterveer, P. (Eds) (2010) Social Perspectives on the Sanitation Challenge (Dordrecht: Springer).

VEWIN (2007) Water in Zicht 2006 (Rijswijk: VEWIN). VEWIN (2008) Dutch Drinking Water Statistics 2008 (Rijswijk: Vewin). 
Vollink, T. \& Meertens, R. M. (2006) Technological innovations and the promotion of energy conservation: The case of goal-setting and feedback, in: A. Verbeek \& A. Slob (Eds), User Behavior and Technology Development, pp. 139-148 (Dordrecht: Springer).

Wuestenhagen, R., Wolsink, M. \& Burer, M. J. (2007) Social acceptance of renewable energy innovation: An introduction to the concept, Energy Policy, 35(5), pp. 2683-2691.

Zeeman, G. (2009) Centralised or decentralised sanitation chains? in: J. C. v. Dijk, J.Q.J.C. Verberk \& A.A. vanWoerden (Eds), Nieuwe uitdagingen; 6le vakantiecursus in drinkwatervoorziening, 28e vakantiecursus in riolering en afvalwaterbehandeling (Delft: Water Management Academic Press). 